Please do not remove this page

RMIT

UNIVERSITY

\title{
Impersonalisation of electronic money: implications for bank marketing
}

Singh, Supriya

https://researchrepository.rmit.edu.au/esploro/outputs/9921858471101341/filesAndLinks?institution=61RMIT_INST\&index=null

Singh, S. (2004). Impersonalisation of electronic money: implications for bank marketing. International Journal of Bank Marketing, 22(7), 504-521. https://doi.org/10.1108/02652320410567926

Document Version: Accepted Manuscript

Published Version: https://doi.org/10.1108/02652320410567926

Repository homepage: https://researchrepository.rmit.edu.au

(c) Emerald Group Publishing Limited

Downloaded On 2023/04/26 18:25:18 +1000

Please do not remove this page 


\title{
Impersonalisation of electronic money: Implications for
}

\author{
bank marketing
}

By

\section{Supriya Singh}

Associate Professor Supriya Singh is a Senior Research Fellow with the Faculty of Business, RMIT University. She is a sociologist of money and communications. Her previous work in the banking area has been on the history of the Central Bank of Malaysia, bankers in Australia in the 1980s and a study of how money and banking shape and are shaped by social relationships and cultural values. Supriya also heads the User-Centred Design group in the Smart Internet Technology Cooperative Research Centre in Australia.

Associate Professor Supriya Singh

Senior Research Fellow,

Faculty of Business

RMIT University

GPO Box 2476V

Melbourne 3001

Australia

Supriya.singh@rmit.edu.au

Tel: +61 399251327

http://www.rmit.edu.au/bus/rdu/supriya

http://www.ucd.smartinternet.com.au 


\section{Impersonalisation of electronic money: Implications for}

\section{bank marketing}

\section{Abstract}

This paper examines the mismatch between the impersonality of electronic money on the one hand and Australian customers' desire to have a personal banking relationship on the other. This gap is illustrated by a critical appraisal of literature relating to the sociology of money, the adoption of information and communication technologies and self-service technologies. The paper argues that bank marketing professionals adopt an activity-centred social marketing strategy. This strategy places customers and their activities at the center to help ensure a fit between payment activities, services, and values relating to money within different cultural contexts. The strategy has managerial implications, for when payments services are tracked according to customers and activities, the data required is different from data generated by following customer segments and products. An activity-centered social marketing strategy has the potential to increase trust in banks and halt the shift of financial relationships to intermediaries such as brokers and financial planners.

Keywords: “electronic money” “Australia” "payments” "personal relationships" “self-service technologies” "trust” "activity-centred social marketing strategy”

\section{Introduction}

Information and communication technologies (ICTs) in the Western world have increased the use of electronic money and changed the way payments are made for goods and services. In this paper 'electronic money' includes electronic channels such as automated teller machines (ATMs), electronic funds transfer at point of sale 
(EFTPOS), telephone banking, the fax and the Internet. Electronic money also includes payments instruments such as direct transfers, and debit and credit cards used over the telephone or the Internet.

The second section charts the increasing role of electronic money in Australia within the context of international developments. It shows that Australians are using more electronic payments instruments and channels, but cash and cheques remain important. Self-service technologies such as the ATMs are used by the majority of Australians, but face-to-face interaction continues to be central for institutional trust. This section also describes how the closure of branches by major banks in rural Australia is leading communities to seek alternative ways of obtaining face-to-face interaction. Australians are also increasingly turning to non-bank financial intermediaries for personal banking services.

The third section argues the importance of seeing money as a social and cultural phenomenon, rather than just a means of economic exchange. Drawing on the literature around the sociology of money and empirical studies of the use of money, the section shows a gap has emerged between the personal way people think of money and the virtual and impersonal nature of electronic money. The use of ICTs and selfservice technologies have at the same time made some aspects of money more impersonal. In the fourth section electronic money is placed within the frameworks of the adoption of information and communication technologies and technology-based services. The importance of trust is highlighted.

The fifth section recommends that marketing professionals adopt a user/activity-centred social marketing strategy. This strategy focuses on the fit between activity, channel and audience within a cultural context. The paper concludes 
by drawing out the managerial implications of the emphasis on customers and activity.

\section{Greater Role of Electronic Money}

The mix of payments instruments and channels is changing in Australia. Macro statistical data from Australia and international financial institutions show that money is becoming increasingly electronic in much of the Western world. Firstly, direct debit and credit surpassed the value of cheques in Australia in 2001. In the same year, Australians paid more often by credit and debit cards than cheques. However, traditional payments instruments like cheques and cash remain important. Secondly, electronic channels of payment are becoming increasingly important. At the same time, face-to-face interactions and their possibility, continue to be essential to ensure institutional trust and maintain the personal and social nature of banking. The closure of branches of major banks in rural Australia has led communities to seek alternative institutions, which ensure face-to-face interaction and community involvement. Australians are also increasingly using non-bank financial intermediaries for personal advice on money management and mortgages.

\section{Increased use of direct debit and credit}

There has been a perceptible increase in the volume and value of electronic money used in Australia. In 2003, in terms of value, direct credits and debits have overtaken the value of cheques (see table I).

Take in table I

As the Reserve Bank of Australia notes, "For many consumers, electronic means of payment are supplanting the traditional cheque, although the "smart card" 
revolution remains elusive and e-commerce has yet to develop an effective replacement for the cheque for business use" (Reserve Bank of Australia 2003b, p. 2). What we see in Australia is a changing mix of payments, where electronic money is becoming more important (see figure 1).

Take in figure I

The fall of the volume and value of cheques masks their continuing importance as a payments instrument, particularly for business. According to Reserve Bank of Australia data, businesses write around 70 per cent of the volume of cheques and even more in terms of their value (Reserve Bank of Australia, 2003a). The volume of cheques has also declined across the countries monitored by the Bank for International Settlements between 1997 and 2001. However cheques continue to account for 70.7 per cent of the total volume of cashless transactions in Hong Kong SAR and 53.5 per cent in the United States in 2001. In all countries, except Hong Kong SAR, direct transfers are most important by value (Bank for International Settlements 2003).

Cash remains important, even though it is difficult to measure. Customers, particularly those in the lower socio-economic categories and those with limited literacy and numeracy use the boundedness and physical aspects of cash as a budgeting tool (Singh, 1997). The Reserve Bank of Australia says, "Cash remains a convenient payment method for small-value transactions where speed is critical and payment records less important” (Reserve Bank of Australia 2003, p.2). Cash is also likely to "account for the largest number of payments used” (Bank for International Settlements 2003, p. 3). The cash economy in Australia is estimated to be worth up to 
\$Aus 20.7 billion in potential tax revenue (Birnbauer, 2003). Cash is important for paying for goods and services in China, Hong Kong, Japan, Korea, Malaysia, the Philippines, Singapore and Thailand (EMEAP Working Group on Payment and Settlement Systems, 2002).

\section{Increased use of electronic channels of payment}

Most Australians use EFTPOS and the telephone to pay for goods and services. The use of ATMs is at a high level, but relatively stagnant. The Internet is increasing in importance as a payments channel but it is still minimal in its impact. The latest household data from Australian Bureau of Statistics show that:

- In 2000, 74 per cent of Australians, 18 years and over, withdrew funds via Automated Teller Machines (ATMs) (Australian Bureau of Statistics, 2001);

- 66 per cent of adults had used Electronic Funds Transfer at Point of Sale (EFTPOS) to pay bills or withdraw funds (Australian Bureau of Statistics, 2001);

- In 2002, 23 per cent of adults had used the Internet to pay bills or transfer funds (Australian Bureau of Statistics 2003).

In Australia all banks offer Internet banking. The growth in the number of customers has been dramatic since 2001. By early 2003, it is estimated that over 40 per cent of Australian adults (6.5 million) were using the Internet for banking (Paul Budde Communication Pty Ltd 2003). Inquiring about cheque account balances is the most popular transaction amongst Australian users. However an increasing number of people are now transferring money between accounts and paying bills over the Internet. Online banking users make an average of one transaction a week (The Australian 2002, July 10).

Traditional channels of payment - the branch, mail, and payment over the counter - continue to remain important. In Australia, bank branch numbers have been 
declining since 1993. There were 7,064 bank branches in June 1993 and 4,858 in June 2003 (Reserve Bank of Australia 2004). Even with these closures, data from the Executives’ Meeting of East Asia-Pacific Central Banks and Monetary Authorities (EMEAP) show that Australia is second only to Japan in the number of bank branches per million inhabitants in Asia and Australasia. Australia ranks the highest for post office branches (EMEAP Working Group on Payment and Settlement Systems 2002).

\section{Rural communities seek alternatives to banks}

Despite the figures that Australia still has a large number of bank branches, the closure of bank branches, particularly in rural Australia has been met with a sense of disquiet. Rural communities have sought alternatives that show an important aspect of banking is its role in building and maintaining communities. This connection between rural communities and banks is rooted in history, as Australian banks opened early in rural areas to service the mining and wheat industries. Often the bank was one of the first institutions to move into a new community, the banker being one of the main community leaders (Singh, 1991).

The closing of bank branches in Australia has been driven by cost savings. Bank strategists assumed electronic channels and self-service technologies would mostly replace the physical presence of banks. But as the adverse reaction against the closures show, the branch's importance goes beyond transactions. Moreover, consumers wishing to engage in electronic transactions also see the physical presence of a bank as important for generating trust (Furst, Lang and Nolle, 2002; Kimber, 2001). The closure of branches in rural and regional Australia, has meant a lessening of access. It signals the banks' devaluing of rural customers and is a factor in the decline of rural communities. As one banker told a Parliamentary Standing Committee, the adverse reaction against bank closures "has been more over the fact of 
what we are doing to the town rather than focusing on the reduction in banking services necessarily” (Parliament of Australia House of Representatives 1999, p. 29). The same connection between the loss of banking branches, bank jobs and rural business is heard in the new hearings by the Parliamentary Joint Committee on corporations and financial services that began in 2002 (Chapman 2003, 17 March).

Some communities that have lost bank branches have moved their face-to-face transactions to Rural Transaction Centres or Community Banks. The Community Banks, a franchise of Bendigo Bank, aim to have the community own and manage the bank. Much of the profit is channeled back into the community. The community banks have been a success in communities that want to manage change. This is especially true if the communities have a history of operating collectively (Jennings, $2002)$.

\section{Customers move increasingly to other financial intermediaries}

The personal aspect of banking is particularly evident with some financial activities like getting a mortgage or financial advice. These activities involve a greater degree of risk for the customer and hence demand more trust than electronic money and channels as yet provide. These financial decisions also flow from and influence a wide gamut of personal choices. There are signs that customers are seeking the personal attention they desire for these financial activities through other financial intermediaries, such as mortgage brokers and financial planners - whether they are linked or not to banks.

Banks have outsourced the personal aspect of banking by using intermediaries

- either in-house or related - to offer personal financial services such as financial advice, home loans, superannuation and stock broking. It is estimated bank in-house financial advisers comprise 15 per cent of the financial planning market (Australian 
Securities Investment Commission (ASIC) 2003). Mortgage brokers in Australia account for 23 per cent of home loans from banks, building societies and credit unions (Consumer Credit Legal Centre (NSW) Inc 2003 . In New Zealand, in 2001, mortgage brokers provided approximately 25 to 27 per cent of all new residential home loans written by banks. In the United States estimates range from 50 to 90 per cent (Drylie, Matthews and Tripe nd). There is little however on the public record which argues the profitability of each of these strategies.

The personal delivery of financial services has appeal even in a situation where non-bank intermediaries have not established a significant measure of trust. Much of the literature from the consumer perspective suggests that a number of mortgage brokers and financial planners are driven by commissions from the financial institutions, rather than the interest of their customers. Hence trust in these intermediaries is at risk, making a case for greater disclosure, self-regulation and government regulatory action (Australian Securities Investment Commission (ASIC), 2003; Consumer Credit Legal Centre (NSW) Inc, 2003).

\section{The Social and Cultural Context of Electronic Money}

The sociology of money has for the last two decades shown that money is a social phenomenon belonging to the market and the non-market aspects of social life. The central notion in this literature is that money shapes and is shaped by social relations and cultural values. These ideas challenge the concept of money that is prevalent in banking, economic policy and law - that money is a wholly economic phenomenon related to the market alone; that it is a universal, homogenous commodity which is only distinguished by quantity. The insights of the sociology of money are crucial for marketing professionals, as much of the dissatisfaction around the management of money, stems from the social and cultural aspects of money. The cultural aspects are 
particularly important, as electronic money needs to be designed so as to match the meanings of money across cultures.

Drawing on the theoretical and empirical literature of the sociology of money, this section makes three points. Firstly, it shows that customers continue to expect a personal regard for their money. At the same time however, electronic forms and channels of money are making money more virtual and impersonal. Secondly, the new technologies around money have the potential to change the way money is managed at home. The evidence we have suggests that the control of money in some households is becoming more male. Thirdly, the new technologies and self-service technologies are changing payments behaviour in a way that is challenging earlier values around money.

\section{Money is a social phenomenon}

Viviana Zelizer's work has been central to the sociology of money, showing that money is shaped and shapes social relations and cultural values. Before Zelizer, the classical sociologists saw money and society as important, but saw it as a one-way relationship. Money impacted on society, but the nature of money itself remained unchanged. They continued to see money as homogenous, defined by quantity. Money belonged to the market. When money intruded into the personal sphere, money defiled personal relationships (See \{Marx, [from 1927] 1971 \#418;Simmel, 1990 \#144;Weber, 1947 \#417\}.

Zelizer's historical work on insurance, and household money, shows there are different kinds of money that exist in the market and outside it. She says, not all dollars are equal. Housekeeping money is qualitatively different from an inheritance; wages are different from bonuses. These different kinds of money are earmarked and 
separated according to source and use. They have different meanings and are managed differently (Zelizer, 1994).

Nigel Dodd's contribution is that a person's use and perception of money is what distinguishes money from non-money. To be money, it has to be part of a social network of trust (Dodd, 1994). This approach differs from the traditional economics definition, where money is defined in terms of three basic functions. Money is seen as a medium of exchange; a store of value and a unit of account. However as Dodd points out money in modern economies does not always perform these three functions. Currency, for instance, is not always a good store of value and securities are not always a good medium of exchange. There is also nothing inherent in a slip of paper or a piece of plastic that distinguishes them from objects that are not seen as money. The paper or plastic is accepted as money only because they are part of a social network of trust. We say they are money, we accept it as money, and so it is money. This point is particularly important as the transfer of electronic money, is a transfer of information even for the residential consumer. Behind the non-use of electronic money lies the lack of trust in electronic networks and the security of the exchange between the two parties. Electronic money only works if there is an established network of trust and meanings around that form of money.

\section{Money becomes virtual}

Electronic money is virtual for it cannot be held, touched and seen. In an important sense all money is "virtual" as money is an abstract way of measuring value (Ingham, 1998). Georg Simmel in The Philosophy of Money (Simmel, 1990) noted even earlier that the system of money is abstract, impersonal and symbolic. But electronic money is "virtual" in that compared with cash, cheques and the branch, the payments instrument and/or the channel is no longer physical. 
The greater use of electronic money has led to a gap between our use of money and the way we continue to speak of it. Wilson (1999) in her study of the meanings of money in Anglo-Celtic Australia says, "Childhood influences remain relevant no matter what physical form the official currency takes. As it is, our underlying attitudes to money have changed far less than the system that dispenses our money" (Wilson 1999, p. xvi).

Another Australian study of money in banking and marriage (Singh, 1997) also shows we continue to speak of tangible, physical money as "real money" as distinguished from "plastic money". In this sense, cash - that is notes and coins - are “real money”, something we can touch and hold, see or store. (Singh, 1997).

The lack of physicality about electronic money and often with the record of electronic money has one important effect. The electronic part of domestic money is first and foremost experienced as information. Money has been information for banks ever since they exchanged money through IOUs, bills of payment, and the SWIFT network. But this transformation of money to a mode of electronic information is new for the household. This transformation becomes crucial for the management and control of household money.

\section{Money becomes impersonal}

The virtuality of money has made money transactions more impersonal. Often the choice to transact across the counter - despite unsatisfactory service - is an attempt to retain a valued personal sense of money.

The use of impersonal electronic channels has changed the social meanings of money. In Australia, the direct crediting of wages means that earnings are no longer cash in hand. Savings become the money that is left over after expenditure (Singh, 1997). Research in the 1990s showed that middle income Australians continued to see 
banking relationships as personal; that credit was a personal commitment and that a mortgage was the single most important personal investment decision. The personal nature of banking and money thus clashed with the growing use of electronic money. Much of the anger against banks was directed at the impersonalisation of banking, where this personal dimension was not recognized (Singh, 1997). Consumer satisfaction surveys also show that one of the important reasons for continuing dissatisfaction with banks, is because of the lack of personal attention (Halls, 2002).

\section{Is electronic money more male?}

This section argues that electronic money has the potential to change the balance of power over money in the household.

Sociological studies of the management and control of money in the household untangle the way different people exercise power over money. The idea of the household as a "black box" where resources are distributed equally has long been challenged in sociology and increasingly in economics. Because electronic money transforms money into information, the control of money now rests with the control of information.

Some of the technologies make for more jointness in money management. In Anglo Celtic Australia, the joint account is an important aspect of managing money in marriage - particularly when there are children and the wife is not in full paid work. In such a context, the Automated Teller Machines (ATMs), EFTPOS and credit cards give information about balances in the account and money spent, without the need for direct questioning (Singh, 1997).

However Internet banking and the electronic management of finances have the potential to give control of the money to the partner who is comfortable with the electronic technologies. Jan Pahl in the United Kingdom has examined how electronic 
money - "invisible money" - changes some of the traditional arrangements. She says, “...new forms of money may be changing and individualizing the financial arrangements of married couples.” (Pahl, 1999, p. 73).

Pahl also cautions that electronic forms of money continue to be associated with male territory. Men's greater use of new forms of money and technology, such as Internet banking and computerized account keeping is changing the gender balance of financial power within families. She says, “The man who keeps the accounts for the couple on his computer spreadsheet has more power in financial matters than the woman, who simply gives him the information to enter on that spreadsheet” (Pahl, 1999, p. 73). Singh and Ryan's (1999) work on gender, money and electronic commerce also arrives at the same conclusions.

\section{Electronic money changes payments behaviour}

Electronic channels and forms of money have changed the meanings and management of money. The greater use of plastic cards for the payment of goods and services, for instance, has also led to a change in the meanings of everyday payments. In the early 1990s, in Australia, credit cards were seldom used for paying for groceries. Cash was the preferred way. Cash was familiar, "real" and physical. It was easier to control the flow of cash, for it was immediately evident how much money had been spent and how much money remained. Cash and food were strongly associated in most households because most households allocated the largest portion of their disposable cash income to regular food shopping. Paying for groceries on credit was seen as the beginning of a slippery slope to debt and a loss of control over the budget. This is why when a form of electronic money was chosen, it was more likely to be direct debit via EFTPOS than a credit card (Singh, 1997; Wilson 1999). 
This strong association of cash and grocery shopping in Australia has now been overturned. In 1996 in Australia only 10 per cent of consumers paid for supermarket groceries with a card. But in 2000, the comparable figure is 34 per cent. There has been an even greater rise in the use of credit cards for council rates, school fees, insurance payments and car registrations (KPMG Consulting, 2001).

This increased use signals a greater trust in the record of a credit card transaction over the last four years. Australian banks have encouraged the use of the credit card with loyalty programmes, and by providing increased channels by which credit card payments can be made. The change to credit cards signifies that credit cards are no longer seen as impersonal. It could also mean that some domestic transactions such as those for food, are no longer invested with the same personal meanings within the household.

The increased use of self-service technologies (SSTs) also points to the impersonalisation of some money transactions. As Meuter, Ostrom et al (2000) say SSTs are being used for customer service, transactions and self-help mainly over the telephone, Internet and in interactive kiosks. One of the main criteria for satisfaction is that SSTs offer relative value over other ways of transaction, particularly when immediate service is needed and no other channels are available. But part of this relative advantage for a few customers in Meuter, Ostrom et al's (2000) study was that SSTs helped avoid bad service by employees. The customers perceived they could do better themselves. Satisfaction with SSTs means "Growing numbers of customers interact with technology to create service outcomes instead of interacting with a service firm employee” (Meuter, Ostrom et al., 2000, p. 50). In the next section the impact of such "service outcomes" on the firm will be discussed. But the increasing use of SSTs in the financial arena, and reliance on "service encounters via 
machine interaction” (Lee and Allaway, 2002) rather than interacting with customer service employees, also indicates that some dimensions of domestic money are becoming less personal.

\section{The Use of Electronic Money}

The sociology of money sees money as a social phenomenon shaping and being shaped by social relations and cultural values. There is a similar interrelationship in the sociological literature around information and communication technologies (ICTs). This body of work offers a different perspective on the use of electronic money, focusing on the channel and technology, rather than the nature of money. It is equally important for marketing professionals for it challenges one of the main assumptions behind banking strategy.

Much of the interest around information and communication technologies (ICTs) in the banking industry has centred around the reduced cost of the transaction for the bank and the greater convenience of electronic channels and payments instruments for the customers. It has been assumed that price is one of the main reasons for a switch to electronic money. The focus on the reduced costs of individual transactions - that is the Internet transaction as compared with the telephone, ATM or counter transaction - has led to the conclusion that bank profitability will increase as customers use electronic channels for most of their banking. The causal relationship between Internet banking and profitability is still unclear (Furst, Lang and Nolle, 2002). As Brown and Duguid have noted "Trying to transform the way work is done and simultaneously save money is usually a mistake." (Brown and Duguid 2000, p. 82). In this section, however, the focus is on the literature on the diffusion of innovations in general and the growing use of SSTs in particular. This literature shows that price is an important but not a determining factor of adoption. 
E. M. Rogers' (1995) work on the diffusion of innovations has been influential. He says,

Innovations that are perceived by individuals as having greater relative advantage, compatibility, trialability, observability, and less complexity will be adopted more rapidly than other innovations (p.16).

The recent literature on the satisfaction criteria around SSTs highlight the importance of user control and relative advantage. This literature is in tandem with that of Rogers' work in that the categories overlap.

Lee and Allaway (2002) tested the importance of personal control to the adoption and use of SSTs in a study of 240 undergraduate and graduate students at a large southern university. They saw personal control in terms of predictability, controllability, and outcome desirability. They found that the "adoption process of an SST seems to be most effectively facilitated when potential customers are provided with all three types of personal control" (Lee and Allaway, 2002, p. 566). Meuter, Ostrom at al (2000) found that satisfaction with SSTs is their "ability to bail customers out or immediate or troubling situations..." (p. 59). A second major category is the "relative advantage that customers perceive they get from using an SST." (p. 59). The reasons for dissatisfaction include technology failure, process failure, and design that is not customer-centred. A few customers saw that they themselves had made mistakes with the technology. Szymanski and Hise (2000) find "that convenience, site design, and financial security are the dominant factors in consumer assessments of e-satisfaction." (p. 309)

This literature highlights the complexity around adoption and use of new technologies and brings to the fore, issues of trust and cultural meanings. Lee and Allaway's (2002) focus on user control brings us to the heart of trust. Meuter, Ostrom 
et al (2000) say, one aspect of future research is "to examine the implications that arise from the inherent characteristics of SSTs. For example, how should a firm go about developing trust with customers when there is an absence of human contact? How does the lack of human contact affect loyalty, and what are the determinants of service loyalty regarding SSTs?" (Meuter, Ostrom et al. 2000, p. 62)

\section{Trust and the use of electronic money}

Trust is a nebulous concept, difficult to define. People speak of trust most clearly when they speak of a lack of trust. However, people only use the technologies they trust. This trust is not only connected with a familiarity with technology, fears of security, but is rooted in cultural beliefs and patterns.

In banking, technological and policy literature there has been extensive discussion of the technological and legal underpinnings of a secure payments environment. Security is a necessary condition for trust and use, but it is not a sufficient condition. The ATM has become an increasingly important way to withdraw cash and get information about the account balance. However, banks have not been able to persuade these customers to deposit in ATMs. In Australia, only 1 or 2 per cent of deposits are made through ATMs (Allard, 1996).

According to David Bollier:

It may be conceptually useful to distinguish between issues of "hard trust," which involve authenticity, encryption, and security in transactions, and issues of "soft trust," which involve human psychology, brand loyalty, and userfriendliness...it is important to see that the problems of engendering trust are not simply technical in nature.... Trust 
is also a matter of making psychological, sociological, and institutional adjustments (Bollier, 1996, p. 21).

An empirical study of trust and electronic money in Australia (Singh and Slegers, 1996) showed the criteria that engender "soft trust" in electronic money and commerce, fall into three clusters - control, comfort, and caring. Many of the nontechnical and non-economic factors that influence usage fall into these clusters.

Trust is also deeply rooted in cultural beliefs. Hsiao (2003) in his study of Singapore small and medium sized enterprises' adoption of e-commerce distinguishes between reliability-related and value-oriented distrust. Hsiao says,

While technical remedies may reduce reliability-related distrust by removing adoption barriers and restoring online trust, they may still be ineffective in overcoming value-oriented distrust. To analyze valueoriented distrust within the context of e-marketplace adoption, it is essential to examine how a society's socio-cultural structure affects economic activities (p. 169).

\section{An Activity-Centred Social Marketing Strategy}

This section argues that a customer-centred marketing strategy needs to ensure the bank provides a mix of communication channels that fits the requirements of customers for different activities within their social and cultural contexts. Like relationship marketing, this strategy places the customer rather than the transaction at the centre of the strategy. However, unlike some of the recent writings on relationship marketing in an electronic era, this strategy does not depend on classifying customers by their use of information technology nor on their personality characteristics (Lang and Colgate, 2003; Kapoulas, Murphy and Ellis, 2002). 
It is critical to recognize the importance of the fit between channel, activities, audiences and meanings in the social and cultural context (Singh, 2001). An activity centred marketing social marketing strategy has the potential to lead to greater trust, a higher retention of customers, an increased share of their business, and more customer satisfaction.

This customer satisfaction would result from the match between the information that is desired for a particular activity in a social and cultural context, and the information that is yielded by the payments instrument and transaction channel. Cash for instance gives immediate information about money spent, money still in hand, with discretion as to whether the payment is recorded or not. Comfort in the transaction is further increased because it is physical and personal. The cheque remains an important way of paying for businesses in Australia, because the information on the cheque stubb fits the need for a reliable money trail for accounting and evidence (See Table 2 for more detail). With electronic money, there is a greater need for a match between the information yielded by the payments instrument and channel on the one hand, and the information needed for the activity on the other. This is because electronic money is virtual and the context is impersonal (Singh, 1999).

Take in Table 2

Work on transaction services has also shown, that often customers adopt a mix of channels, for different aspects of an activity. As Kimber (2001) says, a typical mortgage scenario might be for the customer to research the mortgage over the net, phone a call centre to check out further details, but actually sign up for the mortgage 
face-to-face in the branch. This use of a mix of channels is to ensure the fit between the kind of information yielded by a channel and product with the information that is required by the person. It is also a function of the kind of communication that is best received by the person at the receiving end of the transaction.

The classification of customer types assumes a customer will behave in the same way irrespective of activity and cultural context. The same person may willingly be an early adopter of one technology only to stick with the old technologies that have worked for other activities. A customer who uses the Internet for information on his or her accounts, may want to talk with a financial adviser across the kitchen table when it comes to advice. This is because the kind of information the person wants in relation to financial advice has to help him or her make personal and family choices. As shown in figure 2, the mix of channels is important for all customers, not just the "naïve” users.

Take in figure 2

A study of small and medium sized businesses in Australia emphasises the importance of the fit. It also demonstrates knowing your audience in choosing the communication channel. A person who could not wait for satellite technology to forecast the amount of fertilizer needed in a field; who used the mobile phone as soon as it was available; and who had a LAN and electronic financial management systems - at the same time walked to the bank every Thursday to deposit the cheques. He also used an old but tried telephone exchange system. With the industry association, there was a modem connection, and updated price lists came electronically. Customers however ordered face-to-face or telephoned the order through. The order was later 
confirmed by fax. Just because the small business was in some ways an early adopter, did not translate to using electronic communication channels in all contexts (Singh and Slegers, 1998).

The fit between information, activity, channel and audience makes for effective communication and greater user control. This fit has to take into account meanings of money in different cultural contexts and service expectations associated with different communication channels. Customer surveys show that for e-mail, the acceptable wait for 90 per cent of the customers is four hours (Rein Research Inc., 1998).

\section{Conclusion: Implications for managers}

An activity centred social marketing strategy, like relationship marketing, has the customer at the centre. It ensures the bank has the story according to the customer's perspective, as well as its own. The emphasis then shifts to ensuring customer satisfaction as well as achieving business objectives.

Connecting perspectives involves "seeing differently" (Brown, 1997). Brown says,

Seeing differently means learning to question the conceptual lenses though (sic) which we view and frame the world, our businesses, our core competencies, our competitive advantage, and our business models. ... If there is anything that is actually coming into focus today, it is the realization that we need to question much of what we think we know about how to conduct commerce, including marketing, distribution, service, and the notion of competition itself. Hardest of all, we need to be able to think about changing the architecture of our revenue streams, that is, the way we make money (p. $\mathrm{x}$ ). 
Going back to figure 2, we see the story from the customer's perspective. The customer is at the centre. The focus is on activities. The social and cultural context frames the inquiry. The picture that is revealed is that of a mix of channels for different activities.

In figure 3, this story is told from the perspective of an organisation that wants to save transaction costs and move activities to the Internet. The Internet is at the centre, the channel for varied activities. If figure 3 is the only story behind bank strategy, then moving more business from other channels to the Internet will be seen as imperative. But if customers and activities are at the centre, as in figure 2, then it is apparent that the Internet can usefully supplement the mix of channels for different activities. Framing the customer's story within the social and cultural context brings to the fore the social and cultural meanings of money and the multiple factors that influence the use of new technologies.

Take in figure 3

This process of seeing differently is hard won, for it involves the language of meaning and the language of numbers; the frameworks of sociology and communication studies as well as those of economics and technology. It involves seeking an understanding of money, payments and banking as social and cultural activities, as well as economic activities influenced by price. The sociological studies of money, banking and technology however point to some actions that can help managers connect the customer/activity perspectives to those of their organisation and banking in general. 
- See banking from the organizational and customer/activity perspective as in figures 2 and 3 and try and connect these two stories;

- While offering electronic options, make available a mix of transaction and communication channels;

- Seek data for transactions according to the kind of customer, activity and channel, so as to design the balance of channels in the mix;

- Ensure that information provided for electronic money matches the needs of the customer for that particular activity and audience;

- Use a variety of electronic channels as "rich" media to enhance opportunities for contact that is virtual but personal;

- Keep up to date with new technologies such as smart personal agents, and conversational interfaces, which aim to give the customer more control over digital communication. The challenge is to assure these agents are trusted and the network is secure.

As Lee and Allaway (2002) say for SSTs, giving customers more personal control in the design and delivery of services, “does not necessarily mean either higher costs or lower operational efficiency of the service delivery system" (p. 567). Managers consciously taking these steps will at the very least question the self-sufficiency of the organizational story. At best, the organizational language and perspectives will change to ensure the fit between activity, information, channel and audience within particular social and cultural contexts.

\section{References}

Allard, T. (1996, 11 May) "We're withdrawn on ATM deposits”, The Sydney Morning Herald. 
The Australian (2002, July 10), Seniors fuel online banking growth in Australia, Available (The Australian OCTOBER $27 \quad$ 2002) http://www.nua.ie/surveys/index.cgi?f=VS\&art_id=905358150\&rel=true

Australian Bureau of Statistics (2001), Household Use of Information Technology, 2000, Australian Bureau of Statistics, Canberra.

Australian Bureau of Statistics (2003), Household Use of Information Technology, 2001-2002, Catalogue Number 8146.0. Australian Bureau of Statistics, $\begin{array}{lllll}\text { Canberra } & \text { (Available } & 17 & \text { February }\end{array}$ http://www.ausstats.abs.gov.au/ausstats/subscriber.nsf/Lookup/AAD3580B50 B6A970CA256D9D00057958/\$File/81460\%5F2001\%2D02.pdf

Australian Payments Clearing Association (2004), Payment Statistics. Available (17 February 2004) http://www.apca.com.au/Public/apca01_live.nsf/WebPageDisplay/payments_s ystems?OpenDocument

Australian Securities Investment Commission (ASIC) (2003), Survey on the Quality of Financial Planning Advice, Available 27 May 2003) http://www.fido.asic.gov.au/asic/pdflib.nsf/LookupByFileName/Advice_Repo rt.pdf/\$file/Advice_Report.pdf

Bank for International Settlements (2003), Statistics on Payment and Settlement Systems in Selected Countries. Available (2 September 2003) http://www.bis.org/publ/cpss54p2.pdf

Birnbauer, W. (2003), Cash in hand, The Age, Melbourne.

Bollier, D. (1996) The Future of Electronic Commerce: A Report of the Fourth Annual Aspen Institute Roundtable on Information Technology. The Aspen Institute, Aspen, Colo. 
Brown, J. S. (1997) "Introduction", In Brown, J. S. (ed) Seeing differently: Insights on Innovation, Harvard Business Review, Boston, pp. ix-xxiii.

Brown, J. S. and Duguid, P (2000), The Social Life of Information, Harvard Business School Press, Boston.

Chapman, G. (2003, 17 March), Inquiry hears crucial evidence from South Australian rural communities.Available $\quad(2 \quad$ December 2003) http://www.senatorchapman.com/pcrural.htm

Consumer Credit Legal Centre (NSW) Inc. (2003), A Report to ASIC on the Finance and Mortgage Broker Industry, Australian Securities Investment Commission, Surry Hills, NSW. (Available 17 February 2004) http://www.asic.gov.au/asic/pdflib.nsf/LookupByFileName/finance_mortgage brokers_report.pdf/\$file/finance_mortgagebrokers_report.pdf

Dodd, N. (1994), The Sociology of Money: Economics, Reason and Contemporary Society, Polity Press, Cambridge.

Drylie, S., Matthews, C. and Tripe, D. (nd), Do Mortgage Brokers have clients' best interests at heart? How do New Zealand mortgage brokers select a lending bank? Unpublished paper.

EMEAP Working Group on Payment and Settlement Systems (2002), Payment $\begin{array}{lll}\text { systems } & \text { in }\end{array}$ http://www.rba.gov.au/PaymentsSystem/PaymentsPolicy/PaymentsInOtherCo untries/payment_systems_in_emeap_economies_0702_full_report.pdf

Furst, K., W. W. Lang, et al. (2002), Internet banking: Developments and prospects, Program on Information Resources Policy, Harvard University, Cambridge, Mass. 
Halls, B. (2002), Customer satisfaction: don't bank on it, 20http://aca.ninemsn.com.au/stories/1163.asp accessed 2 May 03.

Hsiao, R.-L. (2003), "Technology fears: distrust and cultural persistence in electronic marketplace adoption", The Journal of Strategic Information Systems, Vol 12 3, pp 169-199. http://www.sciencedirect.com/science/article/B6VG34991WSB-1/2/d93b2c42e43869e8cf762140de0282cb accessed 3 December 03.

Ingham, G. (1998). "On the Underdevelopment of the 'Sociology of Money'." Acta Sociologica 41, pp. 3-18.

Jennings, A. (2002), "Local people rebuilding local economies", Community Development Journal, Vol 37 No 4, pp 300-315.

Kapoulas, A., Murphy, W. and Ellis, N. (2002). "Say hello, wave goodbye: missed opportunities for electronic relationship marketing within the financial services sector?" International Journal of Bank Management Vol 20 No 7, pp.302-310.

Kimber, C. (2001), "Strategic integration of customers and channels", Journal of Financial Services Marketing, Vol 5 No 4, pp 332-336.

KPMG Consulting (2001), Credit cards in Australia: A research report, Nolan Norton Institute, KPMG Consulting, Melbourne.

Lang, B. and Colgate, M. (2003). "Relationship quality, on-line banking and the information technology gap." International Journal of Bank Management 21(1), pp. 29-37.

Lee, J. and A. Allaway (2002), "Effects of personal control on adoption of self-service technology innovations." Journal of Services Marketing 16 (6), pp. 553-572. 
Marx, K. ([from 1927] 1971), "Economic and philosophical manuscripts", Karl Marx: Early Texts. In D. McLellan (ed), Economic and philosophical manuscripts, Basil Blackwell, Oxford, pp. 130-183.

Meuter, M. L., A. L. Ostrom, et al. (2000), "Self-service technologies: Understanding customer satisfaction with technology-based service encounters," Journal of Marketing 64 (3), pp. 50-64.

Pahl, J. (1999), Invisible money: Family finances in the electronic economy, The Policy Press, Bristol.

Parliament of Australia House of Representatives (1999), Regional banking services: Money too far away. Available (1 March 1999) http://www.aph.gov.au/house/committee/efpa/rbs/rbsrep.htm

Paul Budde Communication Pty Ltd (2003), Australia-E Commerce - Internet Banking (incl. online trading and mortgages), Paul Budde Communication Pty Ltd, Bucketty, NSW.

Rein Research Inc. (1998), Citizens First, Citizen-Centred Service Network and the Canadian Centre for Management Development, Canada.

Reserve Bank of Australia (2003a). "The changing Australian Retail Payments Landscape." Reserve Bank of Australia Bulletin, July, pp. 1-9. Available 17 February 2004) http://www.rba.gov.au/PublicationsAndResearch/Bulletin/bu_jul03/bu_0703_ 1.pdf

Reserve Bank of Australia (2003b), Payments System Board Annual Report 2002, Reserve Bank of Australia, Sydney. Available (9 December 03) http://www.rba.gov.au/PublicationsAndResearch/AnnualReports/PaymentsSys tem2002/index.html 
Reserve Bank of Australia (2004), Points of Access to the Australian Payments System. Available February 2004) http://www.rba.gov.au/Statistics/Bulletin/C05hist.xls

Rogers, E. M. (1995), Diffusion of Innovations. $4^{\text {th }}$ edition, The Free Press, New York,

Simmel, G. (1990), The Philosophy of Money Trans. by , 2nd ed. London: Routledge \& Kegan Paul, Routledge \& Kegan Paul, London.

Singh, S. (1991), The Bankers: Australia's Leading Bankers Talk of Banking Today, Allen \& Unwin, St. Leonards, NSW.

Singh, S. (1997), Marriage Money:The Social Shaping of Money in Marriage and Banking, Allen \& Unwin, St. Leonards, NSW.

Singh, S. (1999), "Electronic money: Understanding its use to increase the effectiveness of policy", Telecommunications Policy, Vol 23 No 10\&11, pp. 753-773.

Singh, S. (2001). "Studying the user: A matter of perspective." Media International Australia 98(February), pp.113-127.

Singh, S. and Ryan, A. (1999), Gender, Design and Electronic Commerce, CIRCIT at RMIT, Melbourne.

Singh, S. and Slegers, C. (1997) Trust and Electronic Money. Centre for International Research on Communication and Information Technologies, Melbourne.

Singh, S. and Slegers, C. (1998), Small business and electronic commerce, Centre for International Research on Communication and Information Technologies, Melbourne.

Szymanski, D. M. and R. T. Hise (2000). "e-Satisfaction: An initial examination." Journal of Retailing 76(3), pp. 309-322. 
Weber, M. (1947), The Theory of Social and Economic Organization, The Free Press, New York.

Wilson, V. (1999), The Secret Life of Money: Exposing the Private Parts of Personal Money, Allen \& Unwin, St. Leonards, NSW.

Zelizer, V. (1994), The social meaning of money, Basic Books, New York. 
Table I: The relative volume and value of monthly transactions, Australia: 1994, 2003 (Millions of transactions)

\begin{tabular}{|c|c|c|c|c|}
\hline \multirow[t]{2}{*}{ Payment instruments } & \multicolumn{2}{|c|}{$\begin{array}{c}\text { Volume of monthly } \\
\text { transactions } \\
\text { (millions) }\end{array}$} & \multicolumn{2}{|c|}{$\begin{array}{c}\text { Value of monthly } \\
\text { transactions } \\
\text { (\$A billion) }\end{array}$} \\
\hline & 1994 & 2003 & 1994 & 2003 \\
\hline Credit cards & 19.9 & 85.6 & 1.8 & 11.7 \\
\hline Direct credits & 35.0 & 64.5 & 45.2 & 245.5 \\
\hline EFTPOS & 20.6 & 72.5 & 1.1 & 3.9 \\
\hline Cheques & 81.4 & 50.6 & 545.5 & 159.2 \\
\hline Direct debits & 7.2 & 29.6 & 28.8 & 188.8 \\
\hline
\end{tabular}

Source: Australian Payments Clearing Association, 2004 
Figure 1: Relative Importance of Non-cash Retail Payment Instruments (Per cent of value of payments)

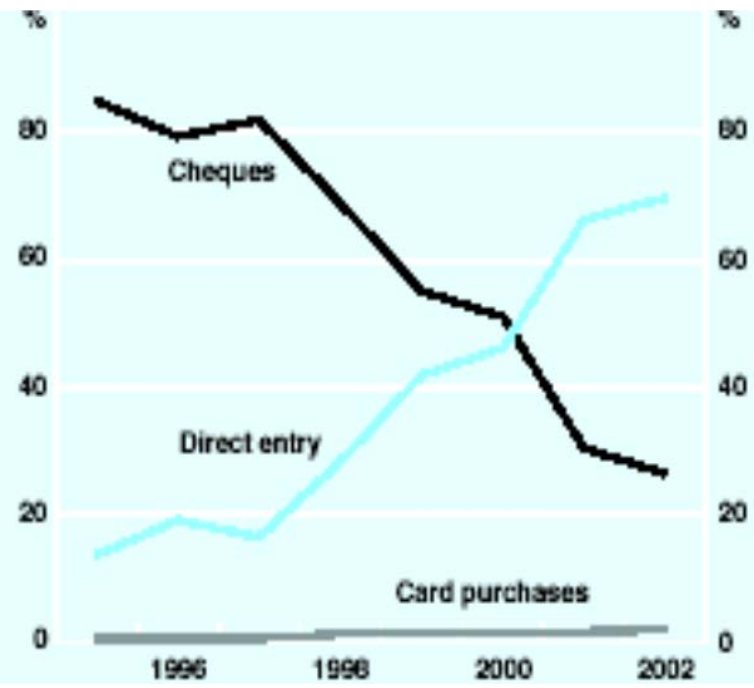

Source: Reserve Bank of Australia 2003a, p. 2 

Table 2: Information Dimensions of Forms of Payment

\begin{tabular}{|c|c|c|c|c|c|c|c|c|c|c|c|}
\hline \multirow{3}{*}{$\begin{array}{c}\text { Payment } \\
\text { instruments/ } \\
\text { Channels } \\
\end{array}$} & \multicolumn{11}{|c|}{ Information Dimensions } \\
\hline & \multicolumn{2}{|c|}{ Time } & \multicolumn{2}{|c|}{ Range } & \multicolumn{4}{|c|}{ Context } & \multicolumn{3}{|c|}{ Immediate Record } \\
\hline & Immediate & $\begin{array}{l}\text { Retrosp- } \\
\text { ective }\end{array}$ & $\begin{array}{l}\text { Money spent } \\
\text { or received }\end{array}$ & $\begin{array}{l}\text { Money in hand } \\
\text { or still in } \\
\text { account }\end{array}$ & Personal & Impersonal & Physical & Virtual & Evidential & Discretionary & Untraceable \\
\hline Cash & $Y$ & & $\mathrm{Y}$ & $\mathrm{Y}$ & $\mathrm{Y}$ & & $\mathrm{Y}$ & & & $\mathrm{Y}$ & $\mathrm{Y}$ \\
\hline ATM cash & $\mathrm{Y}$ & & $\bar{Y}$ & $\bar{Y}$ & & $\bar{Y}$ & $\bar{Y}$ & & $\bar{Y}$ & & \\
\hline $\begin{array}{l}\text { EFTPOS (cash } \\
\text { out) }\end{array}$ & $\mathrm{Y}$ & & $\mathrm{Y}$ & & $\bar{Y}$ & & $\mathrm{Y}$ & & $\bar{Y}$ & & \\
\hline $\begin{array}{c}\text { Cheque (face- } \\
\text { to-face) }\end{array}$ & $\bar{Y}$ & $\mathrm{Y}$ & $\mathrm{Y}$ & & $\bar{Y}$ & & $\bar{Y}$ & & $\mathrm{Y}$ & & \\
\hline $\begin{array}{l}\text { Plastic (face-to- } \\
\text { face) }\end{array}$ & $\bar{Y}$ & & $\mathrm{Y}$ & & $\mathrm{Y}$ & & $\mathrm{Y}$ & & $\bar{Y}$ & & \\
\hline Mail plastic & $\bar{Y}$ & & $\mathrm{Y}$ & & & $\mathrm{Y}$ & $\bar{Y}$ & & & $\mathrm{Y}$ & \\
\hline Phone plastic & $\bar{Y}$ & & $\bar{Y}$ & & & $\bar{Y}$ & & $\bar{Y}$ & & $\bar{Y}$ & \\
\hline Fax plastic & $\bar{Y}$ & & $\bar{Y}$ & & & $\bar{Y}$ & & $\bar{Y}$ & & $\bar{Y}$ & \\
\hline Internet plastic & $\mathrm{Y}$ & & $\mathrm{Y}$ & & & $\mathrm{Y}$ & & $\mathrm{Y}$ & & $\mathrm{Y}$ & \\
\hline & & & & & & & & & & & \\
\hline
\end{tabular}




\begin{tabular}{|l|l|l|l|l|l|l|l|l|l|l|l|}
\hline Direct transfer & & $Y$ & $Y^{*}$ & & $Y$ & & $Y$ & & $Y$ & & \\
\hline
\end{tabular}

Note: * Only if it is a fixed payment.

Source: Modified table, Singh, 1999. 
Figure 2: A mix of channels for retail banking and payments

The Social and Cultural Context

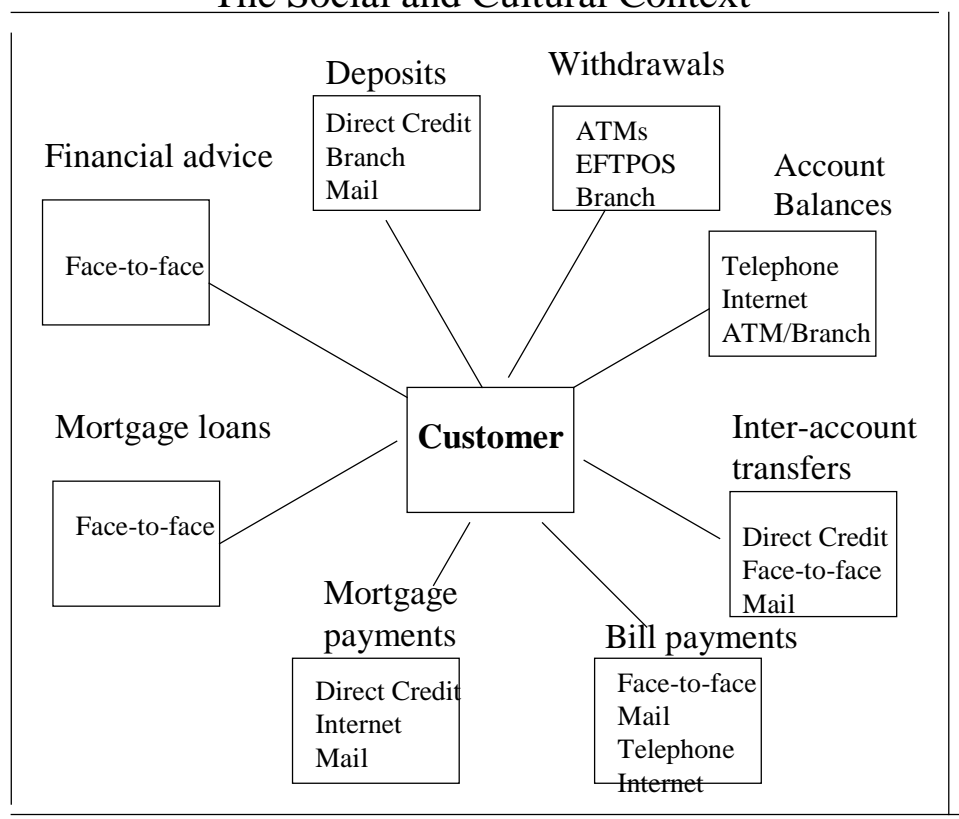


Figure 3: The dominance of the Internet for retail banking activities

The Organisational Context

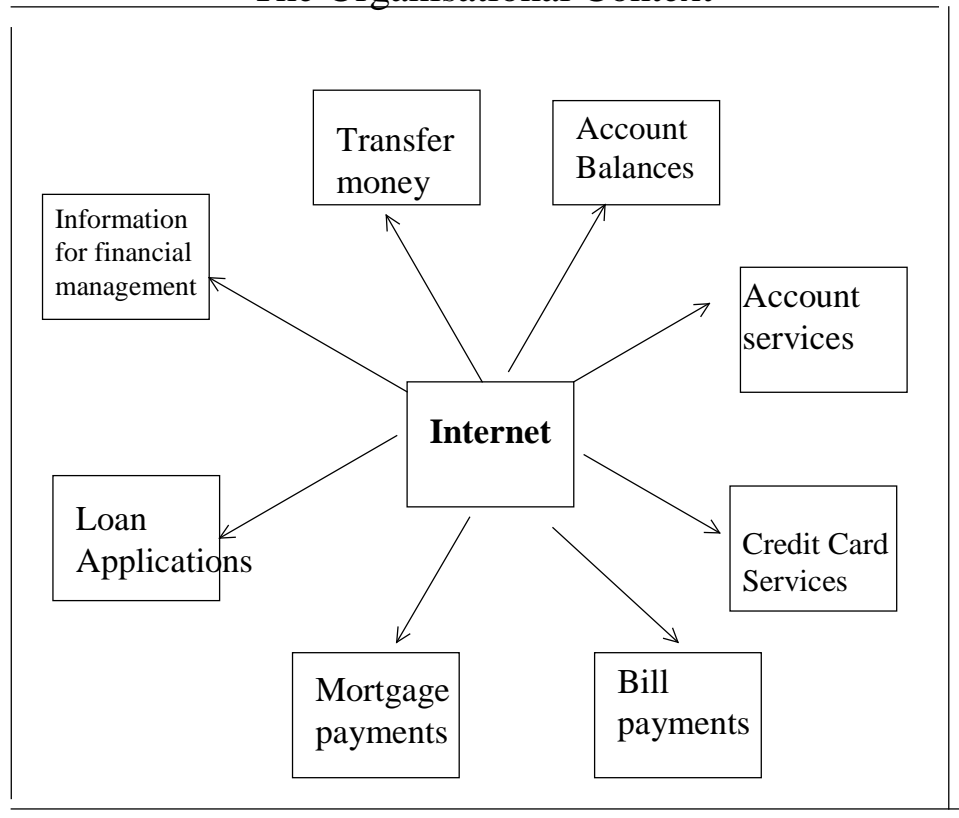

